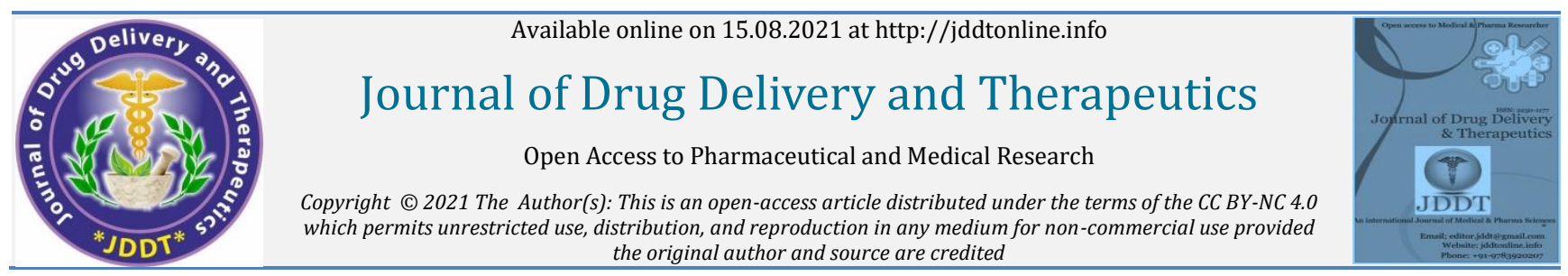

Open Access Full Text Article the original author and source are credited

Review Article

\title{
Recent insights into Early Onset Dementia (EOD): A Review
}

\author{
Jyotirmoy Bondyopadhyay*1, Indrajit Bhattacharya² and Raja Chakraverty ${ }^{3}$ \\ ${ }^{1}$ Assistant Professor of Pharmacology, Hooghly B. C. Roy Institute, Hooghly, India \\ 2 Senior Research Fellow, Department of Pharmacology, Central Ayurveda Research Institute, Kolkata, India \\ ${ }^{3}$ ICMR Research Fellow, Department of Pharmacology, IPGME\&R-SSKM Hospital, Kolkata, India
}

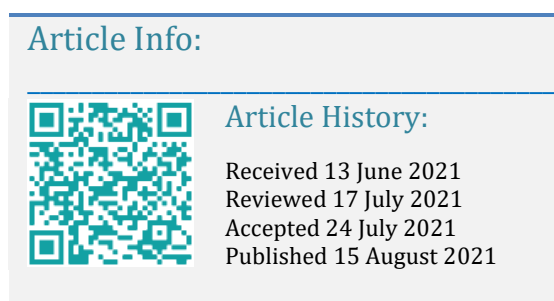

Cite this article as:

Bondyopadhyay J, Bhattacharya I, Chakraverty R, Recent insights into Early Onset Dementia (EOD): A Review, Journal of Drug Delivery and Therapeutics. 2021; $11(4-S): 225-230$

DOI: http://dx.doi.org/10.22270/jddt.v11i4-S.4959

\section{*Address for Correspondence:}

Jyotirmoy Bondyopadhyay, Assistant Professor of Pharmacology, Hooghly B. C. Roy Institute, Hooghly, India

\section{Abstract}

The present study aims to review the prevalence and etiology of Early Onset Dementia (EOD) reflected in the population based studies worldwide. For this purpose, Bibliographic database searches and rigorous literature review were performed using the following keywords namely: "Dementia", "Early onset dementia", "Alzheimer's disease" and "Senile Dementia" from the following databases: Pubmed, Medline between the years 2005 to 2019. The summary of report findings suggest that the prevalence of early onset dementia is reported to occur in 3-5\% of the Indian population among predisposed individuals. This is an attempt to accumulate and collate in one spot all sort of multifactorial associations behind the pathogenesis of EOD in youth. These causes are Genetic change, Brain comorbidities, Alzheimer's ailment, vascular complications and increasingly other neuropsychiatric complications. We have made an attempt to analyze the pathogenesis of the early onset dementia in relation to their outcomes and a few manifestations which demonstrate the same. Future large-scale systematic reviews and network meta-analysis in this domain would facilitate dissemination of credible information with regards to the causative mechanism and possible therapeutic interventions and viable alternatives to possibly tackle and mitigate EOD.

Keywords: Dementia, Early onset dementia, Alzheimer's disease, Genetic alterations.

\section{Introduction}

Dementia, is a disease which say a typically disease of old age and these are generally occurred after the age of $65 .{ }^{1}$ As per the 2001 Census, in India more than 70 million people are older than 60 years. This age group, only $7.5 \%$ of the population in 2001, in the coming decades is expected to grow dramatically. The problem of dementia comes with demographic ageing. In every 5 years the numbers of dementia affected person are increases and the increase rate are double and for these reasons India will become a city where a largest numbers of elders shall be present with this problem. Dementia usually is a chronic syndrome, which characterized by a progressive and global deterioration in intellect including memory, orientation, judgment, learning, comprehension and language due to disease of the brain. Dementia affects mainly older people; and it start before the age of 65 years are noticed only $2 \%$ of cases. ${ }^{1}$ In some cases where dementia are notified before the 65 years, are called Early onset dementia. Generally, 3\%-5\% patient are suffer by this disease. 2, 3, 4, 5 In case of dementia, patient loss their cognitive function and behavioral ability. Normally, it is an age- associated process. Several factors are present in case of early onset dementia. Those are, genetic-abnormalities, which accelerate the onset of the illness. Generally two type of dementia are seen, those are, i) Presenile Dementias, and ii) Senile Dementias. Main cause of presenile dementia are, corticobasal degeneration, progressive supra nuclear palsy and front temporal lobar degeneration. In the presenile age it's generally occurring. It rarely seen also in senile age. In senile age, vascular dementia, sporadic Alzheimer's disease are occur Less frequently it's occur in presenile age. ${ }^{1}$ People with EOD, in their life phase often act as an active role in the society and may have young children. They loss their roles and responsibilities and also they deal with some specific issues those are, difficulties in obtaining a proper diagnosis, unemployment, family conflict, marital problems and financial issues. ${ }^{2,6}$

\section{Diagnosis of Early Onset Dementia:}

Report said that $30-50 \%$ diagnosis case are mistaken or say uncertain. ${ }^{7}$ Therefore several reasons are also arrived for this difficulties. Firstly differences are noticed in EOD diagnosis and LOD diagnosis and that is, the EOD diagnosis more diverse then the LOD diagnosis. Second reasons are, EOD may be present salient cognitive deficits apart from loss of memory in the case of AD. Third reasons are, EOD often take place together with neuropsychiatric characteristics. 7,8

A man or woman who has a psychiatric disorder in his history, then his diagnosis is problematic. In case of EOD patients several step are taken for his diagnosis. First of all they are taking a clinical history of the patient, and at the 
same time also taking a clinical history of dementia. Besides this, carrying on a neurological examination, a factitive MRI and also other tests are needed for the diagnosis. 3,9

In any type of disease, early diagnosis is very much important and it is cardinal. Early treatment can be started if early diagnosis are done and therefore patient family be assured. For this early diagnosis patient family can take the right decision and future plan can be made. 10,11, 12

Comparison shows that the distribution of diagnoses of dementia differs dramatically between older and younger patients. In both groups, Alzheimer's disease is the most common cause of dementia, accounting for almost two-thirds of cases in older people, but only a third of cases in younger people. Comprising between the younger population and older population the Fronto-temporal dementia are occurs mainly in younger population. In younger population, rarer causes of dementia are happen with frequency. ${ }^{10,13,14}$

\section{Symptoms that may indicate Dementia:}

Numerous more seasoned grown-ups experience the ill effects of dementia. Positive responses to the accompanying inquiries can recognize conceivable dementia.

Does the individual have expanded trouble with any of the exercises recorded underneath? In the event that the appropriate response is truly, the person ought to get a dementia evaluation from a specialist. ${ }^{15}$
- Learning and retaining new information.- Is progressively tedious; experiences difficulty remembering ongoing discussions, occasions, arrangements; habitually loses objects. ${ }^{15}$

- Handling complex tasks.- Experiences difficulty following a mind boggling line of reasoning or performing errands that require numerous means, for example, adjusting a checkbook or preparing a dinner. ${ }^{15}$

- Reasoning ability. - Can't react with a sensible arrangement to issues at work or home, for example, comprehending what to do if the restroom is overwhelmed; shows strange dismissal for rules of social direct. 15

- Sense of direction.- Experiences difficulty driving, sorting out articles around the house, discovering their way around natural spots. ${ }^{15}$

- Language.- Has expanding trouble with finding the words to express what the person needs to state and with following discussions. ${ }^{15}$

- Behavior.- Shows up progressively uninvolved and less responsive, is more bad tempered than expected, is more suspicious than expected, misjudges visual or soundrelated upgrades. ${ }^{15}$

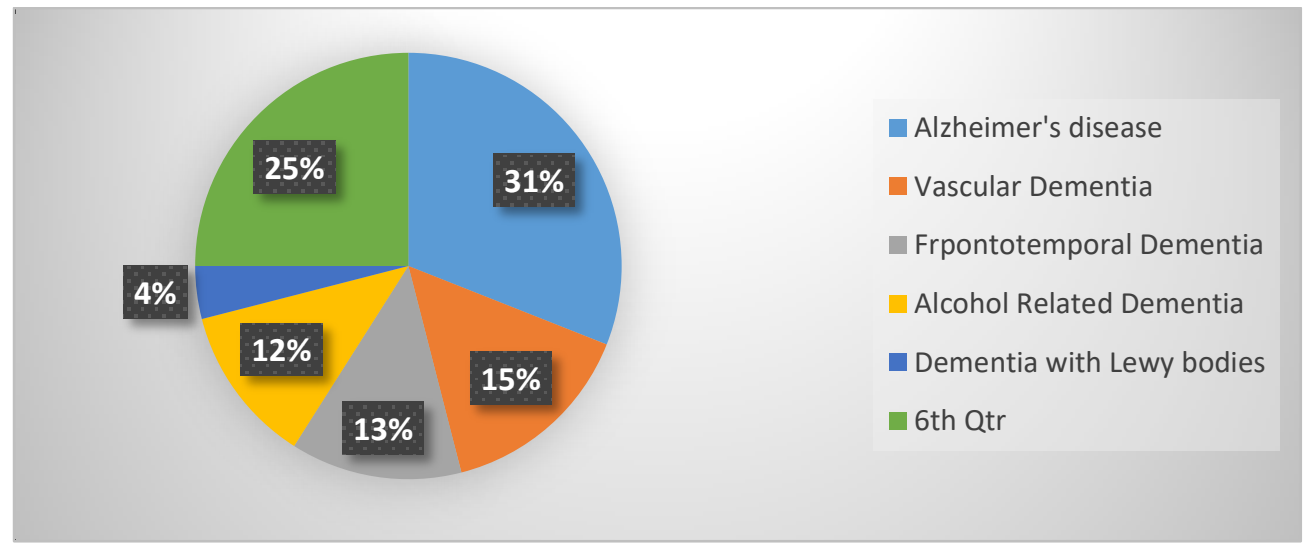

Figure 1: Estimation of judgments in youthful beginning dementia. ${ }^{10}$

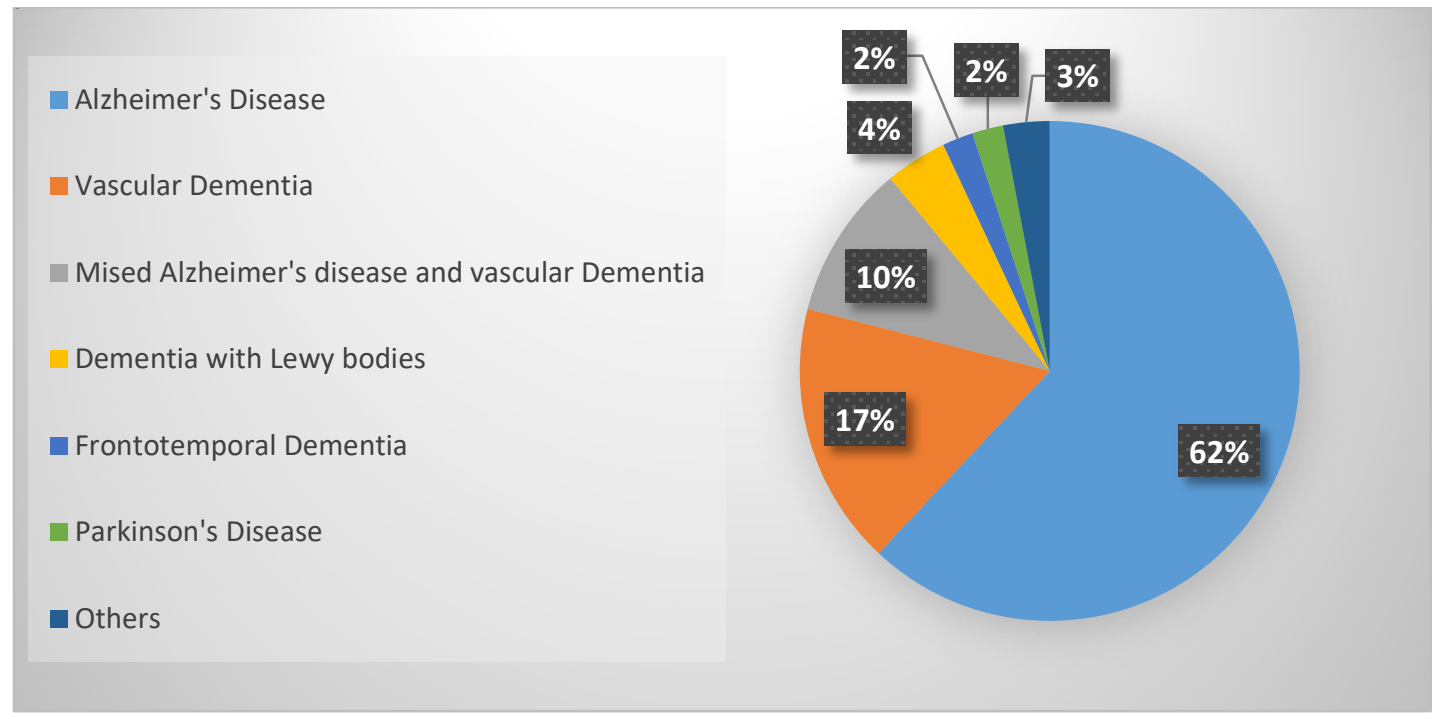

Figure 2: Appropriation of analyses of dementia outcomes .10 


\section{Beginning Dementia Assessment}

Dementia appraisal created by the Care Management Advisory Group of the Chronic Care Networks for Alzheimer's malady activity. Warning Group accept that individuals with conceivable dementia have been recognized utilizing case discovering strategies, for example, supplier training about signs and manifestations of conceivable dementia, utilization of a family survey, or other wellbeing hazard appraisals. It isn't normal that all pieces of the appraisal will fundamentally be executed in one visit, rather a few visits could be required. The aftereffects of the Initial Dementia Assessment (IDA) bolster both the doctor's conclusion and the advancement of a consideration plan and the executives of care over the long haul. The Advisory Group prescribes a three-advance way to deal with evaluation. The assessments and tests recorded in Level 1 ought to be accomplished for all customers. We gauge that 65 percent of customers will require close to this degree of evaluation. Level 2 assessments and tests ought to be accomplished for all customers except if there is relative conviction about the conclusion dependent on the Level 1 data, or the aftereffects of a Level 2 test would not change the consideration plan. We gauge that practically all outstanding customers will be in this classification. Level 3 mediations are once in a while required in the standard appraisal and the executives of dementia in essential consideration settings. Be that as it may, if beginning is early (age < 65), if course is atypical, or if analytic vulnerability is high, they might be useful. ${ }^{15}$

The rounds of Initial Dementia Assessment Level 1 are Interview of the patient, Family interview, Examination (Physical, Neurological, Mental etc.), Laboratory test(CBC, Glucose, TSH, Drug levels etc.), Therapeutic Diagnostic Tests. Rounds of Level 2 are Laboratory Tests (Liver function test, B12 and folate levels, Calcium etc.) Brain Imaging. Rounds of level 3 are Consultation, Neuropsychological Evaluations, Laboratory Tests (Genetic testing, Heavy-metal screen etc.) and Studies (Lumbar puncture, EEG, SPECT, diffusion MRI etc.). 15,16

\section{Different causes of Dementia- 7,10,17,18,19,20,21,22, 23,} $24,25,26,27,28$

\section{Early-Onset Dementia occur due to TREM2 mutations - Without bone cysts. 17,23}

Progranulin gene (PGRN), Chromatin-modifying protein 2B gene (CHMP2B), Valosin-containing protein gene (VCP), Microtubule-associated protein tau gene (MAPT) are to be show the cause of FTLD or frontotemporal lobar degenerations. presenilin 1 (PSEN1), presenilin 2 (PSEN2) and amyloid precursor protein (APP) are smeared in early onset AD. DAP12 named also TYROBP (TYRO protein tyrosine kinase binding protein; MIM\# 604142) and TREM2 (triggering receptors expressed on myeloid cells-2; MIM\# 605086) are responsible for Polycystic Lipomembranous Osteodysplasia with Sclerosing Leukoencephalopathy; MIM\# 221770, an autosomal recessive disease characterized by early-onset progressive dementia and bone cysts. ${ }^{17,23}$

In this research process 382 STR markers are used to locate and recognize the gene which coated in early-onset dementia (EOD) without bone cysts. ${ }^{17,23}$
Early- Onset Dementia and Later Onset Brain Disorders are occur due to TBI (Traumatic Brain Injury) and MTBI (Mild Traumatic Brain Injury)

After doing a successful research work it was notified that the Traumatic Brain Injury which also called TBI and Mild Traumatic Brain Injury called MTBI are epigenetic risk factors. This epigenetic risk factors for organic personality changes, mania, depression, anxiety disorders, schizophrenia, and Parkinson's disease (PD), include obsessive-compulsive disorder, and post-traumatic stress disorder. ${ }^{18}$ MTBI which is more likely to be associated with PTSD than more severe TBI involving loss of consciousness. Recently, some data suggest that Traumatic Brain Injury (TBI) has been identified as a strong positive predictor of developing other brain disorders, such as dementia, including Alzheimer's disease (AD). ${ }^{18}$ Therefore through this Traumatic Brain Injury (TBI) diagnostic procedure of those other brain disorder are accelerated.

\section{Early onset dementia and the Octapeptide repeat insertions in the prion protein gene}

Various genes are known in familial early onset dementias. Mainly the most common mutations are noticed in the genes involved in Alzheimer's disease. This concerns mutations in the APP and the PSEN1 and 2 genes. Again, mutations in the PRNP gene may be common in EOD. ${ }^{29}$

Here sequencing the coding region of amyloid precursor protein, presenilin 1 and 2 and PRNP in a population based sample of 17 patients with EOD and identified in one patient an insertion of two-octapeptide repeats. Here present a meta- analysis in which, studied the relation of the number of inserted repeats with age at onset and duration of disease in all patients with PRNP octapeptide repeat insertions reported in the literature to date. ${ }^{29}$

\section{Alzheimer's disease $10,19,20,21,22,24,25,26$}

For almost one third of early-onset dementia cases are responsible for Alzheimer's disease. A typical presentation of $\mathrm{AD}$ are, progressive episodic memory loss and visuospatial and perceptual deficits, but well preserved language and social functioning. In younger people, posterior cortical variant of the disease, along with prominent impairment of parietal lobe functions, is more common. $\mathrm{AD}$ is more common in women than men. Outbreak increases with increasing age. Total average time of illness is 8 years. In the younger population Alzheimer's disease (AD) are mostly occurs, which is a sporadic disorder. However, traditional forms are more likely in the younger population. $10,19,20,21,22,24,25,26$

\section{Vascular Dementia:}

Vascular dementia is an etiological classification that incorporates clinical type of dementia brought about by ischemic or hemorrhagic cerebrovascular ailment or by ischemic hypoxic mind sore of cardiovascular cause. Vascular dementia is the most well-known reason for dementia after Alzheimer's malady. Vascular dementia brought about by various vascular injuries and pathogenic systems. Those are multi infarct dementia, which are various huge complete infarcts happen in the cortical and sub cortical bit of the cerebrum. Strategic infarct dementia, Small vessel disease with dementia, ischemic-hypoxic dementia and Hemorrhagic dementia. 10,26,28 
Table 1: Depicting the inferences and findings from previous studies

\begin{tabular}{|c|c|c|c|}
\hline Data & Observation & Inference & Ref \\
\hline $\begin{array}{l}\text { TYROBP and TREM2 are liable } \\
\text { for Polycystic Lipomembranous } \\
\text { Osteodysplasia with Sclerosing } \\
\text { Leukoencephalopathy. An } \\
\text { autosomal latent ailment } \\
\text { portrayed by beginning stage } \\
\text { dynamic dementia and bone } \\
\text { pimples. }\end{array}$ & $\begin{array}{l}\text { In this examination, we recognized a novel } \\
\text { cancellation, c. } 40+3 \text { delAGG, in the } 5 \text { ' } \\
\text { agreement giver join site in intron } 1 \text { of TREM2 } \\
\text { in three sibs from a Lebanese family } \\
\text { influenced with beginning stage dementia. } \\
\text { Dementia is a clinically and hereditarily } \\
\text { heterogeneous ailment, including many } \\
\text { recognized loci and qualities. }\end{array}$ & $\begin{array}{l}\text { This outcome expands the clinical } \\
\text { range related with TREM } 2 \\
\text { changes, which ought to be } \\
\text { considered in all patients with } \\
\text { EOD even without bone pimples. }\end{array}$ & 17 \\
\hline $\begin{array}{l}\text { Different qualities are known in } \\
\text { familial beginning stage } \\
\text { dementias. }\end{array}$ & $\begin{array}{l}\text { Discovered an expanding number of rehashes } \\
\text { related with more youthful age at beginning } \\
(\mathrm{p}<0.001) \text {. Term of the ailment diminished } \\
\text { essentially with the length of the octapeptide } \\
\text { rehash }(\mathrm{p}<0.001) \text { while changing for age at } \\
\text { beginning. }\end{array}$ & $\begin{array}{l}\text { Our discoveries show huge } \\
\text { backwards relationship of the } \\
\text { length of the PRNP octapeptide } \\
\text { rehash with age at sickness } \\
\text { beginning and malady span in the } \\
\text { spongiform encephalopathies. }\end{array}$ & 29 \\
\hline $\begin{array}{l}\text { For just about } 33 \% \text { of beginning } \\
\text { stage dementia cases are } \\
\text { answerable for Alzheimer's } \\
\text { illness. Promotion is more } \\
\text { typical in ladies than men }\end{array}$ & $\begin{array}{l}\text { This examination show that, in spite of the fact } \\
\text { that the extent with AD among females stayed } \\
\text { steady at } \sim 70 \% \text {, among guys the extent } \\
\text { expanded continuously from } 38 \% \text { among } \\
\text { those matured } 65-69 \text { years to } 80 \% \text { in those } \\
>90 \text { years old. }\end{array}$ & $\begin{array}{l}\text { Alzheimer's disease is commonly } \\
\text { viewed as the most well-known } \\
\text { dementia subtype, representing } \\
\text { somewhere in the range of } 60 \% \\
\text { and } 80 \% \text { of dementia cases. }\end{array}$ & $\begin{array}{l}10, \\
19,25\end{array}$ \\
\hline $\begin{array}{l}\text { Vascular dementia is the most } \\
\text { notable purpose behind } \\
\text { dementia after Alzheimer's } \\
\text { ailment. }\end{array}$ & $\begin{array}{l}\text { Vascular dementia is the second most regular } \\
\text { reason for dementia in more youthful } \\
\text { individuals. The favoured symptomatic } \\
\text { measures for vascular dementia are the } \\
\text { NINDS-AIREN standards which express that } \\
\text { for a clinical analysis of likely vascular } \\
\text { dementia, both dementia and cerebrovascular } \\
\text { ailment must be available and there must be a } \\
\text { connection between the two issues. }\end{array}$ & $\begin{array}{l}\text { Vascular dementia (VaD) is the } \\
\text { second commonest dementia } \\
\text { after Alzheimer's sickness (AD). } \\
\text { Epidemiological investigations of } \\
\text { this condition experience the ill } \\
\text { effects of numerous weaknesses } \\
\text { identified with meaning of the } \\
\text { illness, indicative models and } \\
\text { evaluation of subjects. }\end{array}$ & $\begin{array}{l}10, \\
26,28\end{array}$ \\
\hline $\begin{array}{l}\text { If there should arise an } \\
\text { occurrence of Fronto temporal } \\
\text { dementia a gathering of } \\
\text { conditions are answerable for } \\
\text { dementia. }\end{array}$ & $\begin{array}{l}\text { This examination, the first to address the issue } \\
\text { of pervasiveness of FTD in a characterized } \\
\text { populace, distinguished } 17 \text { patients with FTD } \\
\text { from a populace of roughly } 300,000 \text { of whom } \\
11 \text { were as yet matured }<65 \text { years. This } \\
\text { created an age-explicit ( } 45 \text { to } 64 \text { years) } \\
\text { pervasiveness of } 15 \text { for each } 100,000 \text {. }\end{array}$ & $\begin{array}{l}\text { FTD is less normal than } \\
\text { Alzheimer's sickness generally } \\
\text { speaking, one examination } \\
\text { thought that it was is as basic in } \\
\text { individuals under age } 65\end{array}$ & $\begin{array}{l}19, \\
30,31\end{array}$ \\
\hline $\begin{array}{l}\text { Horrendous Brain Injury which } \\
\text { additionally called TBI and Mild } \\
\text { Traumatic Brain Injury called } \\
\text { MTBI are epigenetic chance } \\
\text { variables. }\end{array}$ & $\begin{array}{l}\text { Studies show that TBI and MTBI are epigenetic } \\
\text { hazard factors for natural character changes, } \\
\text { schizophrenia, melancholy, insanity, } \\
\text { Parkinson's sickness (PD), and tension issues, } \\
\text { which incorporate over the top urgent issue, } \\
\text { and post-horrendous pressure issue }\end{array}$ & $\begin{array}{l}\text { TBI has been distinguished as a } \\
\text { solid positive indicator of creating } \\
\text { other cerebrum issues, for } \\
\text { example, dementia, including } \\
\text { Alzheimer's infection }\end{array}$ & 18 \\
\hline
\end{tabular}

\section{Huntington's disease}

The trademark set of three of clinical highlights in Huntington's malady are engine issue, subjective issue and passionate issue. However, there are changes among the patients in the time of onset also specific symptoms and the development of illness. Huntington's disease, which is an autosomal dominant disorder and with complete penetrance caused by prolongation of the CAG trinucleotide repeat. In the middle life beginning is generally and the duration of the illness is typically 15-20 years. Diagnostic and predictive testing is available. ${ }^{7}$

\section{Mixed dementia:}

Caused of dementia May combination of $\mathrm{AD}$ and cerebrovascular conditions and compared with people who have only Alzheimer's disease. Those with mixed dementia tend to develop symptoms earlier. 19,32,27,28

\section{Fronto temporal dementia (FTD):}

Here a group of conditions are responsible for dementia, including Pick's disease and primary progressive aphasia that affect the frontal and temporal regions of the brain. The average age of onset for FTD is 50-60; although FTD is less common than Alzheimer's disease overall, one study found it is as common in people under age 65.19,30,31

\section{Lewy body disease:}

It is a progressive, neurodegenerative brain disease and this is the causes of dementia, hallucinations. The movement and gait disorders that are common in Parkinson's disease. 10,19,33 


\section{Bondyopadhyay et al}

\section{Other:}

Cause of dementia in people under age 65 include, Huntington's disease, HIV/AIDS, amyotrophic lateral sclerosis (ALS), progressive supranuclear palsy, Parkinson's disease, multiple sclerosis, chronic alcoholism, Chronic drug abuse, Brain tumors, Traumatic brain injury, Normalpressure hydrocephalus and Creutzfeldt-Jakob disease. ${ }^{19}$

\section{Conclusion}

Reported literature review surrounding Alzheimer's disease has pointed towards associations with activating receptors communicated on myeloid cells- 2 change, major cerebrum injury and other forms of granular brain injury and also vascular dementia, lewy body illness, front-temporal dementia are additionally reasons for this debilitating condition in mid-life. In this review article we have attempted at holistic and multifactorial modalities responsible for the pathogenesis of this form of dementia in the youth population worldwide. Needless to emphasize that large scale systematic reviews and meta-analysis are warranted to corroborate the present findings.

Acknowledgement: The authors would like to gratefully acknowledge all cooperation from their respective institutions in compiling this review article.

\section{Conflict of interest: None}

\section{References}

1. Miyoshi K, What is 'early onset dementia. Psychogeriatrics. 2009; 9(2):67-72. DOI: https://doi.org/10.1111/j.14798301.2009.00274.x

2. Bakker C, Vugt de E. M, Vernooij D. M, Vliet V D, Verhey I. R. F, Koopmans M. C. T. R. Needs in Early Onset Dementia: A Qualitative Case from the Need YD Study. American Journal of Alzheimer's Disease \& Other Dementias. 2010; 25(8):634-640. DOI: https://doi.org/10.1177/1533317510385811

3. Lecrux R. A, Hannequin D, Raux G, Meur Le N, Laquerriere A, Vital A. APP locus duplication causes autosomal dominant Early onset Alzheirma disease with cerebral amyloid angiopathy. Nature genetics. 2006; 38(1):24-26 DOI: https://doi.org/10.1038/ng1718

4. Panegyres K. P, Berry R, Burchell J. Early Dementia Screening. Diagnostics. 2016; 6(1):1-13. DOI https://doi.org/10.3390/diagnostics6010006

5. Lambert A. M, Bickel H, Prince M, Fratiglioni L, Strauss V. E Frydecka D, et al. Estimating the burden of early onset dementia; systematic review of disease prevalence. European Journal of Neurology. 2014; 21(4):1-7. DOI: https://doi.org/10.1111/ene.12325

6. Roman C. G. Vascular dementia revisited: Diagnosis, pathogenesis, treatment and prevention. The medical clinics of north America. 2002; 86(3):477-499. https://doi.org/10.1016/S00257125(02)00008-1

7. Werner P, Stein S. I, Korczyn D. A, Early onset dementia: Clinical and Social aspects. International Psychogeriatrics. 2009; 21(4):631-636 DOI: https://doi.org/10.1017/S1041610209009223

8. Olmo G J, Batlle G. D, Fernandez M. d. M, Huelamo E. d. R, casadevall T, recio T. J, et al. Incidence and subtype of earlyonset dementia in a geographically defined general population. Neurology. 2010; 75(14):1249-1255. DOI: https://doi.org/10.1212/WNL.0b013e3181f5d4c4

9. Vliet V. D, Vugt E.de M, Bakker C, Koopmans M. C. T R, Pijnenburg L. A. Y, Dassen V. J. F. J. M, et al. Caregivers perspectives on the pre-diagnostic period in early onset dementia: a long and winding road.International Psychogeriatrics. 2011; 23(9):13931404. DOI: https://doi.org/10.1017/S1041610211001013
Journal of Drug Delivery \& Therapeutics. 2021; 11(4-S):225-230

10. Jefferies K, Agrawal N. Early-onset dementia. Advances in psychiatric treatment. 2009; 15(5):380-388. DOI: https://doi.org/10.1192/apt.bp.107.004572

11. Knopman S. D, Petersen C. R, Cha H. R, Edland D. S, Rocca A. W. Incidence and Causes of Nondegenerative Nonvascular Dementia. Arch Neurol. 2006; 63(2):218-221. https://doi.org/10.1001/archneur.63.2.218

12. Medina D. L, Rodriguez A. Y. Cognitive impairment of dementia. Journal of behavior. 2012; 4(2):37-44. DOI: https://doi.org/10.5460/jbhsi.v4.2.34106

13. Kemp M P, Holmes C, Hoffmann A M S, Bolt L, Holmes R, Rowden $\mathrm{J}$, et al. Alzheimer's disease: differences in technetium-99m Hmpao spect scan findings between early onset and late onset dementia. J Neurol Neurosurg Psychiatry. 2013; 74(6):715719.DOI: https://doi.org/10.1136/jnnp.74.6.715

14. Rossor N M, Iversen L L, Reynolds P G, Mountjoy Q C, Roth M. Neurochemical characteristics of early and late onset types of Alzheimer's disease. British medical journal. 1984; 288(6422):1961-1984. DOI https://doi.org/10.1136/bmj.288.6422.961

15. Larson B. E, Kukull A. W, Katzman L. R. Cognitive impairment Dementia and Alzheimer's disease. Annu. Rev. Public Health. 1992; 13(1):431-449. https://doi.org/10.1146/annurev.pu.13.050192.002243

16. Williams T, Dearden M. A, Cameron H. I. From Pillar to post -a study of younger people with dementia. Psychiatric Bulletin. 2011; 25(10):384-387 https://doi.org/10.1192/pb.25.10.384

17. Chouery E, Delague V, Bergougnoux A, Koussas S, Louis S. J, Megarbane A. Mutations in TREM2 Lead to Pure Early-Onset Dementia Without Bone Cysts. Human mutation. 2008; 29(9):194-204. DOI: https://doi.org/10.1002/humu.20836

18. Kiraly.A.M, Kiraly J. S. Delayed Sequelae: A Review Traumatic Brain Injury and Mild Traumatic Brain Injury (Concussion) are Precursors to Later Onset Brain Disorders, Including Early Onset Dementia.The Scitinfic World Journal. 2007; 7(1):1768-1776. DOI: https://doi.org/10.1100/tsw.2007.269

19. Harris PB, and Keady J. Living with early onset dementia. Alzheimer's Care Quarterly. 2004; 5(2):111-122.

20. Benedet J. M, Montz R, Delgado B C. R. Alzheimer's Disease and Vascular Dementia: Neuropsychological Differentiation in Clinical Practice. Clinical Gerontologist. 2012; 35(2):1-17. DOI: https://doi.org/10.1080/07317115.2011.641707

21. McKhann M. G, Knopman S. D, Chertkow H, Hyman T. B, Jr. Jack R. C, Kawas H. C, et al. The diagnosis of dementia due to Alzheimer's disease: Recommendation from the National Institute of Aging-Alzheimer's Association Workgroups on diagnostic guidelines for Alzheimer'sdisease.Elsevier. 2011; 7(3):263-269. DOI: https://doi.org/10.1016/j.jalz.2011.03.005

22. Small W. G, Rabins V. P, Barry P. P, Buckhaltz S. N, Dekosky T. S, Ferris H. S, et al. Diagnosis and Treatment of Alzheimer's Disease and Related Disorders. The Journal of American Medical association. 1997; 278(16):1363-1371. https://doi.org/10.1001/jama.1997.03550160083043

23. McMurtray A, Clark G. D, Christine D, Mendez F. M. Early-Onset Dementia: Frequency and Causes Compared to Late-Onset Dementia. Dement Geriatr Cogn Disord. 2006; 21(2):59-64. DOI: https://doi.org/10.1159/000089546

24. McKeith, I.G, Galasko D, Kosaka K, Perry E. K, Dickson D. W, Hansen L. A, et al, Consensus guidelines for the clinical and pathologic diagnosis of dementia with Lewy bodies (DLB): Report of the consortium on DLB international workshop. Neurology. 1996; 47(5):1113-1124. https://doi.org/10.1212/WNL.47.5.1113

25. Sosa-Ortiz L A, Acosta-Castillo I, Prince J. M. Epidemiology of Dementias and Alzheimer's disease. Archives of Medical Research. 2012; 43(8):600-608. DOI: https://doi.org/10.1016/j.arcmed.2012.11.003

26. Heyman A, Wilkinson E. W, Hurwitz J. B, Helms J. M, Haynes S. C, Utley M. C, et al. Early-onset Alzheimer's disease: Clinical 
Bondyopadhyay et al

predictors of institutionalization and death. Neurology. 1987;

37(6):980-984. https://doi.org/10.1212/WNL.37.6.980

27. Zekry D, Hauw J-J, Gold G. Mixed dementia: Epidemiology, diagnosis, and treatment. The American Geriatrics Society. 2002; 50(8):1431-1438. https://doi.org/10.1046/j.15325415.2002.50367.x

28. Hebert R, Brayne C. Epidemiology of vascular dementia. Neuroepidemiology. 1995; 15(5):240-257. https://doi.org/10.1159/000109800

29. Croes A E, Theuns J, Houwing D. J. J, Dermaut B, Sleegers K, Roks $G$, et al. Octapeptide repeat insertions in the prion protein gene and early onset dementia. J Neurol Neurosurg Psychiatry. 2004; 75(8):1166-1170. DOI:

https://doi.org/10.1136/jnnp.2003.020198
Journal of Drug Delivery \& Therapeutics. 2021; 11(4-S):225-230

30. Ratnavalli E, Brayne C, Dawson K, Hodges R. J. The prevalence of frontotemporal dementia. Neurology. 2002; 58(11):1615- 1621. DOI: https://doi.org/10.1212/WNL.58.11.1615

31. Grossman M, Rhee J, Moore P. Sentence processing in frontotemporal dementia. Cortex. 2002; 41(6):764-777 https://doi.org/10.1016/S0010-9452(08)70295-8

32. Langa M.K, Foster L.N, Larson B. E, Mixed Dementia- Emerging Concepts and Therapeutic Implications. JAMA. 2004; 292(23):2901-2908. https://doi.org/10.1001/jama.292.23.2901

33. Tortosa G E, Ingrabam O. A, Irizarry C. M, Hymun T. B. Dementia with Lewy Bodies. JAGS.1998; 46(11):1449-1458 https://doi.org/10.1111/j.1532-5415.1998.tb06016.x 